\title{
Alternatif Kebijakan dalam Upaya Peningkatan Minat Wanita Usia Subur Melakukan Imunisasi Campak dan Rubela
}

\author{
${ }^{1,2}$ Ratna Wulandari, Astrid Novita \\ 1,2 Program Studi Magister Kesehatan Masyarakat Sekolah Tinggi Ilmu Kesehatan Indonesia Maju \\ Jl. Harapan No.50 Lenteng Agung - Jakarta Selatan \\ Email : ${ }^{1}$ ratnawulandariemail@gmail.com, ${ }^{2}$ astridnh.by28@gmail.com
}

\begin{abstract}
Abstrak
Imunisasi Campak dan Rubela pada Wanita Usia Subur (WUS) masih menjadi kategori imunisasi lanjutan pilihan belum diwajibkan. Ibu hamil yang menderita Campak dan Rubela akan memiliki risiko tinggi janinnya mengalami Congenital Rubella Syndrome (CRS). Di Puskesmas Kecamatan Pasar Minggu kunjungan WUS yang melakukan imunisasi Campak Rubela <100 kunjungan dengan 11 kejadian CRS pada Tahun 2017. Penelitian ini merupakan penelitian kualitatif dengan pendekatan studi kasus. Informan dalam penelitian ini meliputi Kepala Puskesmas sebagai Informan Kunci serta Tim Imunisasi Campak Rubela dan. Pengumpulan data dilakukan dengan metode indepth interview. Hasil temuan masalah dalam penelitian ini antara lain ; belum ada data jumlah penderita, belum ada upaya promotif, belum ada anggaran untuk upaya promotif, dan kurangnya koordinasi. Setelah dilakukan analisis dengan metode Urgency Strategy Growth (USG) dan Strenght Weight Opptunity Threat (SWOT), prioritas masalah yang terpilih adalah belum adanya upaya promotif. Usulan alternatif rekomendasi kebijakan terpilih adalah penyusunan Standar Operasional Prosedur Upaya Promotif Kesehatan Imunisasi Campak Rubela untuk WUS, yang meliputi acuan kegiatan, diagram alur dan anggaran biaya. Saran yang diberikan untuk lahan penelitian adalah segera disusun kebijakan untuk pemberian imunisasi Campak dan Rubela dengan prioritas sasarannya adalah WUS untuk mencegah kejadian CRS.
\end{abstract}

Kata Kunci : Imunisasi Measles Rubella, Kebijakan, Promotif Kesehatan

\begin{abstract}
Measles and Rubella immunization in Fertile Age Women (WUS) is still a category of advanced immunization options not yet required. Pregnant women who suffer from Measles and Rubella will have a high risk of their fetus experiencing Congenital Rubella Syndrome (CRS). In the Pasar Puskesmas sub-district, Sunday, WUS visited those who performed Rubella Measles immunization <100 visits with 11 CRS incidents in 2017. This research was a qualitative study with a case study approach. The informants in this study included the Head of the Community Health Center as a Key Informant and the Rubella Measles and Immunization Team. Data collection was carried out by an in-depth interview method. The findings of the problem in this study include; there is no data on the number of sufferers, there has been no promotive effort, there is no budget for promotive efforts, and there is a lack of coordination. After analysis using the Urgency Strategy Growth (USG) and Strength Weight Opportunity Threat (SWOT) method, the priority of the chosen problem is the absence of promotive efforts. An alternative proposal for selected policy recommendations is the preparation of Standard Operational Measures for Promotional Measures for Rubella Measles Immunization for WUS, which includes reference to activities, flowcharts and cost budgets. Suggestions given for research land are immediately compiled policies for measles and rubella immunization with the priority goal being WUS to prevent the occurrence of CRS.
\end{abstract}

Keywords: Rubella Measles Immunization, Policy, Promotive Health 


\section{Pendahuluan}

Penyakit Campak atau Morbili atau Measles merupakan penyakit yang disebabkan oleh virus yang sangat mudah menular dan ditularkan melalui batuk dan bersin. Manusia diperkirakan satu-satunya reservoir, walaupun monyet dapat terinfeksi tetapi tidak berperan dalam penularan. Gejala penyakit campak adalah deman tinggi, bercak kemerahan pada kulit (rash) disertai dengan batuk dan/atau pilek dan/atau konjungtivis akan tetapi sangat berbahaya apabila disertai dengan komplikasi pneumonia, diare, meningitis dan bahkan dapat menyebkan kematian. Penyakit ini sangat berpotensi menjadi wabah apabila cakupan imunisasi rendah dan kekebalan kelompok (heird immunity) tidak terbentuk. Ketika seseorang terkena campak, $90 \%$ orang yang berinteraksi erat dengan penderita dapat tertular jika mereka belum kebal terhadap campak. Seseorang dapat kebal jika telah diimunisasi atau terinfeksi virus campak. Sedangkan penyakit rubella adalah penyakit akut dan ringan yang sering menginfeksi anak dan dewasa muda yang rentan, akan tetapi yang menjadi perhatian dalam kesehatan masyarakat adalah efek teratogenik apabila rubella ini menyerang pada wanita hamil pada trimester pertama.

Penyebab rubella adalah virus golongan RNA yang cepat mati oleh sinar ultraviolet, bahan kimia, bahan asam dan pemanasan. Virus tersebut dapat menular melalui sawar plasenta sehingga menginfeksi janin dan dapat mengakibatkan abortus atau CRS. Infeksi rubella yang terjadi sebelum konsepsi dan selama awal kehamilan dapat menyebabkan abortus, kematian janin atau sindrom rubella konginetal (CRS) pada bayi yang dilahirkan. Gejala penyakit rubella antara lain deman ringan $\left(37,2^{\circ} \mathrm{C}\right)$ dan bercak merah/ rash makulopapuler disertai pembesaran kelenjar limfe di belakang telinga dan sub occipital. Rubella pada anak sering hanya menimbulkan gejala demam ringan atau bahkan tanpa gejala sehingga sering tidak terlaporkan. Sedangkan rubella pada wanita dewasa sering menimbulkan gejala yang lebih ringan dari campak dan terkadang menimbulkan arthritis atau arthralgia. ${ }^{2}$

Menurut Badan Kesehatan Dunia World Health Organization (WHO), Rubella adalah infeksi virus akut dan menular yang umumya memiliki efek samping ringan pada anak-anak, hal ini memiliki konsekuensi serius pada wanita hamil yang menyebabkan kematian janin atau cacat bawaaan yang dikenal CRS. Ketika seorang wanita terinfeksi virus rubella di awal kehamilan, dia memiliki kemungkinan 90\% untuk menyebarkan virus ke janinnya. Hal ini dapat menyebabkan keguguran, lahir mati atau cacat lahir parah yang dikenal dengan CRS. Resiko CRS tertinggi adalah di Negara-negara dimana Wanita Usia Subur (WUS) tidak memiliki kekebalan terhadap penyakit ini (baik melalui vaksinasi atau karena pernah mengalami penyakit rubella). Sebelum diperkenalkan vaksin, terdapat 4 kematian bayi akibat CRS dari 1000 kelahiran hidup. Tingkat CRS tertinggi di wilayah WHO Afrika dan Asia Tenggara dimana cakupan vaksin paling rendah. Negara yang tergabung dalam Rencana Aksi Vaksin Global oleh WHO termasuk Indonesia, telah berkomitmen untuk membuat Indonesia Bebas dari Campak dan Rubella pada $2020 .^{3}$

Sedangkan data risiko CRS tertinggi ditemukan di negara-negara dengan tingkat kerentanan yang tinggi terhadap rubella di kalangan WUS. Persebaran kejadian CRS didunia terdata bahwa terdapat 22.000 bayi dilahirkan dengan CRS di Afrika, diperkirakan berjumlah 46.000 di Asia Tenggara dan hampir 13.000 di Pasifik Barat. Angka kejadian CRS pada negara yang belum mengintroduksi vaksin rubella diperkirakan cukup tingi. Pada tahun 1996 diperkirakan sekitar 22.000 anak lahir dengan CRS di regio Afrika, sekitar 46.000 di region Asia Tenggara dan 12.634 di regio Pasifik Barat. Insiden CRS pada regio yang telah mengintroduksi vaksin rubella selama tahun 1996-2008 telah menurun. Diperkirakan 100.000 kasus CRS terjadi diseluruh dunia setiap tahunnya. Angka kematian yang dilaporkan pada bayi dengan CRS adalah $33 \%{ }^{4}$

Di Indonesia pada tahun 2010 sampai dengan 2015 diperkirakan terdapat 23.164 kasus campak dan 30.643 kasus rubella. Pada tahun 2016 kejadian campak di Indonesia mencapai 6.880 kasus campak terkonfirmasi laboraturium yang terbagi dalam 12-39\% campak pasti dan $16-43 \%$ rubella pasti. Jumlah kasus ini diperkirakan masih rendah dibanding angka sebenarnya di lapangan, mengingat masih banyaknya kasus yang tidak terlaporkan, terutama dari pelayanan swasta 
serta kelengkapan laporan surveilans yang masih rendah. Dampak dari kejadian campak dan rubella yang sangat berbahaya apabila penderita adalah ibu hamil. Pada ibu hamil akan berdampak pada bayi yang dilahirkan menderita CRS atau kelainan bawaan pada bayi baru lahir. Di Indonesia pada tahun 2016 terdapat 979 kejadian CRS baru dari 4,89 juta bayi yang dilahirkan hidup. ${ }^{5}$

Kegiatan imunisasi MR adalah kesempatan yang sangat penting untuk menutupi kesenjangan cakupan imunisasi campak sekaligus menanggulangi kejadian penyakit rubella sehingga diharapkan tidak ada daerah kantong yang akan menjadi sumber penularan, dengan cakupan yang tinggi dan merata minimal 95\%, maka akan terbentuk heird immunity dan memutus rantai penularan campak dan rubella. Komite Penasihat Ahli Imunisasi Nasonal juga telah mengeluarkan rekomendasi pada tanggal 11 Januari 2016 untuk mengintegrasikan vaksin rubella ke dalam program imunisasi campak nasional untuk menurunkan angka kejadian rubella dan CRS. $^{6}$

Langkah Kementerian Kesehatan Indonesia yang telah menggabungkan vaksin Campak (Measles) dan Rubela (Rubella) menjadi satu dosis vaksin MR, dan mengintegrasikan vaksinasi MR dalam jadwal imunisasi nasional mulai tahun 2017 merupakan suatu kemajuan bidang preventif kesehatan dalam menanggulangi penyakit yang dapat dicegah dengan melakukan imunisasi. Namun target penerima imunisasi MR sebatas anak usia 9 bulan sampai dengan $<15$ tahun. Jika melihat kalender imunisasi di Negara lain khususnya Negara Maju atau Negara dengan kejadian campak dan rubella yang rendah, imunisasi MR telah dimasukkan dalam jadwal imunisasi nasional dengan target utama tidak hanya anak tapi juga Wanita Usia Subur (WUS) untuk mencegah terjadinya Conginetal Rubella Syndrome (CRS) pada bayi baru lahir. Berikut beberapa bukti keberhasilan penurunan kejadian CRS pada Negara yang telah memberlakukan imunisasi MR pada WUS. ${ }^{7}$

Di Spanyol, salah satu Negara bagian Eropa, seluruh ibu yang berencana hamil harus dipastikan telah memiliki imun terhadap Campak dan Rubella oleh lembaga Center for Disease Control and Prevention (CPDP). Jika hasil pemeriksaan menunjukkan WUS tersebut tidak memiliki antibodi terhadap campak dan rubella, maka akan diberikan vaksinasi MR dan diminta untuk menunda kehamilan selama 28 hari setelah divaksinasi. Kebijakan ini telah dilakukan di Negara tersebut sejak tahun 2007 dan terbukti telah menurunkan angka kejadian campak dan rubella secara signifikan dari $>70$ kejadian CRS per 1000 kelahiran hidup pada tahun 2007 menjadi <10 kejadian CRS per 1000 kelahiran hidup pada tahun 2015. Jika ditemukan ibu yang telah hamil namun tidak memiliki imun terhadap campak dan rubella, maka tidak akan dilakukan vaksinasi MR, karena CPDP menilai dampak secara teoritis vaksin MR dapat berpotensi menginfeksi janin. Tindakan yang dilakukan adalah mengawasi ibu hamil tersebut sampai dengan persalinan dan diberikan konseling untuk segera imunisasi MR segera setelah bersalin. ${ }^{8}$

Berangkat dari pernyataan-pernyataan tersebut diatas, penulis tertarik mengangkat dan meneliti tema tersebut ke dalam sebuah Penelitian Dengan Judul "Alternatif Kebijakan dalam Upaya Peningkatan Minat Wanita Usia Subur Melakukan Imunisasi Campak Dan Rubela" dengan menyusun alternatif rekomendasi kebijakan operasional tentang deteksi dini penyakit campak dan rubella pada WUS di wilayah Puskesmas Kecamatan Pasar Minggu Jakarta Selatan Tahun 2017.

Ruang lingkup dalam penelitian
terbatas pada menganalisa kebijakan
operasional tentang Imunisasi Campak dan
Rubela Lanjutan untuk Wanita Usia Subur.
Tujuan dari penelitian ini adalah menentukan
identifikasi masalah, menentukan kriteria
evaluasi kebijakan, merumuskan alternatif
kebijakan operasional tentang upaya
meningkatkan minat Wanita Usia Subur
(WUS) dalam melakukan Imunisasi Campak
dan Rubela.

Metode

Penelitian ini merupakan jenis desain penelitian kualitatif dengan pendekatan studi kasus. Menurut Cresswell penelitian kualitatif bertujuan untuk mendeskripsikan atau melukiskan realitas sosial yang kompleks yang ada di masyarakat. ${ }^{11}$ Pendekatan studi kasus adalah studi yang mengeksplorasi suatu masalah dengan batasan terperinci, pengambilan data mendalam, dan menyertakan 
berbagai sumber informasi. Penelitian deskriptif kualitatif adalah jika data yang disajikan berupa cerita dari para responden atau informan tentang pertimbangan, pengalaman, pengetahuan, atau pandangan hidup mereka. Penelitian deskriptif digunakan untuk menggambarkan dan mengevaluasi dan rekomendasi kebijakan operasional tentang imunisasi MR untus WUS. $^{12}$

Penelitian ini dilaksanakan di Puskesmas Kecamatan Pasar Minggu Kota Administrasi Jakarta Selatan Provinsi DKI Jakarta. Alasan pengambilan tempat penelitian ini didasari karena Puskesmas Kecamatan Pasar Minggu merupakan salah satu Puskesmas yang memberikan fasilitas imunisasi MR untuk WUS. Selain itu tingginya cakupan pelayanan yang dicapai oleh Puskesmas Kecamatan Pasar Minggu membuat Puskesmas tersebut dapat dijadikan sebagai contoh Puskesmas lainnya. Penelitian ini dilaksanakan pada bulan Januari 2018.

Penentuan informan yang digunakan dalam penelitian ini adalah purposive sampling yaitu tehnik pengambilan sampel sumber data dengan pertimbangan tertentu. ${ }^{13}$ Pertimbangan tertentu yang dimaksud adalah pihak-pihak yang terkait dengan kebijakan imunisasi Campak dan Rubela di Puskesmas Kecamatan Pasar Minggu, yang pertama adalah informan kunci yakni Kepala Puskesmas Kecamatan Pasar Minggu yang sebagai penentu kebijakan di Puskesmas Kecamatan Pasar Minggu. Kedua adalah informan pendukung dipilih dengan kriteria pihak yang paling mengetahui tentang imunisasi MR, baik imunisasi MR program maupun imunisasi MR untuk Calon Pengantin Wanita (CPW) yakni Tim Imunisasi MR terdiri dari 3 orang. Ketiga yakni informan pendukung lain yang digunakan adalah pengguna atau WUS itu sendiri sebagai sasaran pelaksanaan kebijakan. Dalam penelitian ini dari 20 WUS yang telah dilakukan wawancara diperoleh pengulangan informasi yang sama atau sejenis, sehingga peneliti hanya mengambil 4 sampel yang dianggap dapat mewakili. Informasi yang diberikan oleh informan dianggap cukup dan berhenti ketika tidak ada informasi baru lagi, terjadi replikasi atau pengulangan variasi informasi, mengalami titik jenuh informasi. ${ }^{14}$ Maksudnya, informasi yang diberikan oleh informan berikutnya tersebut sama saja dengan apa yang diberikan oleh para informan sebelumnya.

Dalam teknik pengumpulan data dalam penelitian ini digunakan metode wawancara mendalam (indepth innterwiew). Teknik pengumpulan data wawancara mendalam adalah proses mendapatkan keterangan untuk tujuan penelitian dengan cara melakukan tanya jawab sambil bertatap muka antara pewawancara dengan responden atau orang yang diwawancarai dengan atau tanpa menggunakan pedoman. ${ }^{15}$ Dalam penelitian ini wawancara mendalam dilakukan dengan menggunakan instrumen wawancara yakni daftar pertanyaan khusus untuk masingmasing jenis informan, dan alat bantu untuk rekaman digital (handphone) untuk meningkatkan ketelitian dalam menangkap informasi.

Data yang didapatkan kemudian dilakukan validasi data untuk memeriksa keabsahan data. Dalam penelitian ini validasi data menggunakan teknik triangulasi dalam penelitian ini dilakukan dengan cara menggunakan triangulasi sumber, yakni dengan melakukan wawancara berulang kepada informan yang berbeda dengan pertanyaan yang berbeda dengan substansi yang sama. ${ }^{16}$ Dalam triangulasi sumber, peneliti sebaiknya tetap berpedoman kepada pencarian data jenuh, yakni informan merasa yakin atas informasi yang diberikan dengan memberikan pertanyaan berulang. ${ }^{17}$

Sumber data untuk triangulasi dalam penelitian ini adalah informan penelitian yakni Kepala Puskesmas, Tim Imunisasi MR, dan WUS. Pertanyaan pokok dalam instrument penelitian terdiri dari 3 hal, yakni ; kebijakan imunisasi MR untuk WUS yang sudah ada, pelaksanaan kebijakan imunisasi MR untuk WUS, dan cara mengatasi kendala dalam pelaksanaan kebijakan imunisasi MR. Berdasarkan analisa hasil wawancara diperoleh data dari Kepala Puskesmas yaitu kebijakan imunisasi MR yang ada saat ini ditujukan kepada WUS, namun belum ada kebijakan dalam upaya meningkatkan jumlah kunjungan WUS, sehingga diperlukan anggaran dan upaya promotif dalam meningkatkan jumlah WUS yang datang untuk melakukan imunisasi MR. Informan kedua yakni Tim Imunisasi MR yang berjumlah 3 
orang dengan hasil wawancara mendalam adalah saat ini sudah ada kebijakan untuk melakukan imunisasi MR dewasa namun hanya untuk calon pengantin wanita yang berusia subur, sebaiknya imunisasi MR lebih dipromotifkan lagi untuk meningkatkan minat WUS dalam imunisasi MR, salah satu kegiatan yang dapat dilakukan adalah dengan melakukan penyuluhan kesehatan. Informan ketiga adalah WUS yang berjumlah orang, sebagian dari informan tersebut belum mengetahui bahwa ada imunisasi MR untuk dewasa dan sebagian lainnya mengetahui, mereka berharap hendaknya jika ada kebijakan lebih diinformasikan ke masyarakat melalui penyuluhan kesehatan baik di Puskesmas atau di rumah warga.

Berdasarkan hal tersebut maka dapat ditarik hasil triangulasi yakni kebijakan imunisasi MR di tempat penelitian saat ini sudah ada, namun belum ada upaya dalam menginformasikannya ke masyarakat, kendala yang muncul adalah belum adanya anggaran operasional khusus dalam kegiatan promotif kesehatan sehingga alternatif rekomendasi kebijakan yang dapat dilakukan adalah dengan melakukan penyuluhan di dalam gedung Puskesmas dengan menggunakan alat yang sudah ada. Semua informan memberikan keterangan yang sejenis dengan bahasa yang berbeda, namun hasil pertanyaan berulang informasi yang didapatkan sama sehingga dapat disimpulkan bahwa data yang diperoleh valid.

Selanjutnya dilakukan analisa data yakni dengan melakukan analisis Urgency Serious and Growth (USG) yakni Urgency (U) adalah mendesaknya suatu permasalahan yang harus ditangani, Serious (S) tingkat keseriusan yakni apakah isu tersebut perlu dibahas berdasarkan akibat yang timbul dari

penundaan pemecahan masalah yang mengakibatkan isu tersebut semakin berkembang, Growth (G) kecenderungan berkembang yakni apakah isu menjadi berkembang makin memburuk kalau dibiarkan. Penilaian USG dimaksudkan untuk menentukan issu mana yang paling dominan untuk pemecahan masalah yang dihadapi dalam melaksanakan Kebijakan Imunisasi MR pada WUS di Puskesmas Kecamatan Pasar Minggu. Alasan ini dituangkan dalam suatu matrix untuk menghitung total nilai USG tersebut. Pemilihan alternatif issu aktual yang ada kemudian dilakukan melalui rating scale (skala nilai), pemilihan ini dikonversi secara kualitatif seperti sangat kuat, kuat, cukup kuat, kurang kuat, dan tidak kuat, yang dapat dijelaskan sebagai berikut:

1. Sangat kuat nilainya 5 memiliki nilai keterkaitan yang sangat kuat

2. Kuat nilainya 4 memiliki nilai keterkaitan yang kuat

3. Cukup kuat nilainya 3 memiliki nilai keterkaitan yang cukup kuat

4. Kurang kuat nilainya 2 memiliki nilai keterkaitan yang kurang kuat

5. Tidak kuat nilainya 1 memiliki nilai keterkaitan yang tidak kuat

Setelah dilakukan analisis USG maka akan ditemukan alternatif prioritas masalah terpilih. Kemudian dilakukan analisis Strenght Weaknes Opportunity Threat (SWOT), analisis SWOT perlu dilakukan karena analisis ini akan mencocokkan "fit" antar sumber daya internal dan situasi eksternal. ${ }^{18}$ Pencocokan yang baik akan memaksimalkan kekuatan dan peluang dan meminimumkan kelemahan dan ancamannya. Analisis SWOT dilakukan dengan dua cara yakni analisis faktor internal/ IFE (Internal Factor Evaluation) dengan menggunakan matrix untuk menyimpulkan dan mengevaluasi kekuatan dan kelemahan, dan analisis faktor eksternal/EFE (External Factor Evaluation) untuk mengetahui potensi dari dalam dan dari luar dari suatu kebijakan yang akan diambil. Identifikasi faktor eksternal peluang dan ancaman serta identifikasi faktor internal kekuatan dan kelemahan. Penilaian dalam analisis ini adalah dengan membuat range untuk setiap faktor antara 0,0 bila tak penting dan 1,0 bila paling penting. ${ }^{19}$

Hasil analisis SWOT nantinya akan menghasilkan informasi bagaimana suatu kebijakan dapat disusun berdasarkan kekuatan dan peluang yang ada dengan mengantisipasi kelemahan yang ada dan ancaman yang muncul. ${ }^{20}$ Kemudian hasil analisa tersebut dapat dipergunakan untuk menyusun alternatif rekomendasi kebijakan dengan metode Quantitative Strategies Planning Matrix (QSPM) yakni dengan menilai skor masingmasing alternatif rekomendasi kebijakan 
dengan menilai berdasarkan tingkat daya tarik (attractive score) dengan range 1 sangat tertaik dan 0 tidak tertarik.

Data hasil penelitian yang telah dianalisa kemudian akan diintreprestasikan dalam bentuk narasi dan tabel. Narasi adalah penyampaian informasi dengan pengembangan paragraf dalam rangkaian tulisan. Sedangkan penyajian data dalam tabel adalah dengan tampilan data dalam bentuk angka dan kata yang tersusun dengan garis pembatas.

\section{Hasil dan Pembahasan}

Hasil analisis kebijakan dalam penelitian ini adalah yang pertama analisis Keputusan Menteri Kesehatan No. 12 tahun 2017 tentang Penyelenggaraan Imunisasi menjelaskan bahwa imunisasi lanjutan pada WUS terdiri dari imunisasi difteri dan tetanus, sedangkan imunisasi Campak Jerman (Rubella) masih termasuk dalam kategori imunisasi pilihan. Hal tersebut menunjukkan bahwa imunisasi Campak dan Rubela untuk WUS belum diwajibkan, sehingga tidak ada keharusan untuk setiap WUS untuk mendapatkan imunisasi Campak dan Rubella. Sejauh ini Pemerintah hanya menetapkan imunisasi Tetanus Toxoid untuk Wanita Usia Lanjut khususnya untuk calon pengantin wanita bagi WUS yang berencana bereproduksi.

Tempat penelitian dalam hal ini Puskesmas Kecamatan Pasr Minggu, hingga saat ini belum memiliki prosedur khusus untuk melakukan upaya peningkatakan minat WUS dalam melakukan imunisasi MR. Hal tersebut dikarenakan Puskesmas Kecamatan Pasar Minggu mengacu pada Keputusan Menteri Kesehatan No. 12 Tahun 2017 tentang Imunisasi, yakni hanya imunisasi MR untuk anak yang diwajibkan. Sehingga keutamaan imuisasi MR masih untuk anak dan belum ada upaya promotif untuk usia dewasa.
Pada saat penelitian dilakukan ditemukan beberapa faktor yang menyebabkan

pelaksanaan Kebijakan Imunisasi MR untuk WUS belum optimal sehingga perlu dilakukan perbaikan untuk meningkatkan Kebijakan tentang Imunisasi MR untuk WUS di Puskesmas Kecamatan Pasar Minggu. Adapun faktor-faktornya sebagai berikut :

1. Belum ada data tentang penderita campak dan rubella pada ibu hamil atau WUS

2. Belum ada kebijakan untuk meningkatkan pengetahuan WUS tentang imunisasi MR

3. Belum ada anggaran dalam usaha promotif imunisasi MR untuk WUS

4. Belum adanya koordinasi dalam usaha promotif kesehatan tentang imunissasi MR untuk WUS antara tenaga kesehatan di ruang poli kebidanan, ruang bersalin dan ruang nifas.

5. Selanjutnya dari empat faktor tersebut dilakukan penilaian tingkat urgensinya sebagai berikut:

Penilaian Urgency, Serious dan Growth (USG) dimaksudkan untuk menenukan issu mana yang paling dominan untuk pemecahan masalah yang dihadapi dalam melaksanakan Kebijakan Imunisasi MR pada WUS di Puskesmas Kecamatan Pasar Minggu. Alasan ini dituangkan dalam suatu matrix untuk menghitung total nilai USG tersebut. Pemilihan alternatif issu actual diatas dilakukan melalui Rating Scale (skala nilai), pemilihan ini dikonversi secara kualitatif seperti; Sangat kuat, kuat, cukup kuat, kurang kuat, dan tidak kuat, yang dapat dijelaskan sebagai berikut:

1. Sangat kuat yaitu angka 5 memiliki nilai keterkaitan yang sangat kuat

2. Kuat yaitu angka 4 memiliki nilai keterkaitan yang kuat

3. Cukup kuat yaitu angka 3 memiliki nilai keterkaitan yang cukup kuat

4. Kurang kuat yaitu angka 2 memiliki nilai keterkaitan yang kurang kuat

5. Tidak kuat yaitu angka 1 memiliki nilai keterkaitan yang tidak kuat 
Maka permasalahan itu dipandang sebagai issu sentral sebagaimana termuat pada tabel sebagai berikut :

Tabel 1. Analisis USG dalam Isu Aktual Imunisasi MR pada WUS

\begin{tabular}{|c|l|c|c|c|c|c|}
\hline No. & \multicolumn{1}{|c|}{ Isu Aktual } & U & S & G & Total Nilai & Rank \\
\hline 1 & $\begin{array}{l}\text { Belum ada data tentang penderita campak dan } \\
\text { rubella pada ibu hamil atau WUS }\end{array}$ & 3 & 4 & 4 & 11 & IV \\
\hline 2 & $\begin{array}{l}\text { Belum ada kebijakan untuk upaya promotif untuk } \\
\text { meningkat-kan pengetahuan WUS tentang } \\
\text { imunisasi MR }\end{array}$ & 5 & 5 & 5 & 15 & I \\
\hline 3 & $\begin{array}{l}\text { Belum ada anggaran dalam upaya promotif } \\
\text { imunisasi MR untuk WUS }\end{array}$ & 3 & 4 & 3 & 10 & III \\
\hline $\begin{array}{l}\text { Belum adanya koordinasi dalam upaha promotif } \\
\text { kesehatan tentang imunisasi MR untuk WUS } \\
\text { antara tenaga kesehatan di ruang; poli kebidanan, } \\
\text { bersalin dan nifas }\end{array}$ & 5 & 4 & 5 & 14 & II \\
\hline
\end{tabular}

Tabel 2. Matrixs Internal Faktor Evaluation (IFE)

\begin{tabular}{|l|l|l|l|l|}
\hline No. & \multicolumn{1}{|c|}{ Kritikal Faktor } & Bobot & Rating & Score \\
\hline \multicolumn{5}{|c|}{ Streght (Kekuatan) } \\
\hline 1 & $\begin{array}{l}\text { Puskesmas Kecamatan Pasar Minggu melayani imunisasi MR untuk } \\
\text { WUS }\end{array}$ & 0,2 & 4 & 0,8 \\
\hline 2 & $\begin{array}{l}\text { Tenaga Kesehatan di Puskesmas Kecamatan Pasar Minggu mampu } \\
\text { melakukan pemberian imunisasi MR }\end{array}$ & 0,3 & 4 & 1,2 \\
\hline 3 & $\begin{array}{l}\text { Konseling imunisasi MR telah rutin dilakukan di ruang Poli Kebidanan } \\
\text { untuk Calon Pengantin }\end{array}$ & 0,5 & 4 & 2,0 \\
\hline & \multicolumn{1}{|c|}{ Jumlah } & \\
\hline 1 & $\begin{array}{l}\text { Belum ada kebijakan untuk meningkatkan pengetahuan WUS tentang } \\
\text { imunisasi MR }\end{array}$ & 0,5 & 5 & 0,25 \\
\hline 2 & $\begin{array}{l}\text { Belum semua tenaga kesehatan di Puskesmas Kecamatan Pasar Minggu } \\
\text { yang berusia 16 - 49 tahun telah diberikan imunisasi MR }\end{array}$ & 0,4 & 4 & 1,6 \\
\hline 3 & $\begin{array}{l}\text { Belum adanya koordinasi dalam usaha promotif kesehatan tentang } \\
\text { imunissasi MR untuk WUS antara tenaga kesehatan di ruang poli } \\
\text { kebidanan, ruang bersalin dan ruang nifas }\end{array}$ & 0,3 & 3 & 0,9 \\
\hline 4 & Belum ada anggaran dalam usaha promotif imunisasi MR untuk WUS & 0,2 & 2 & 0,4 \\
\hline 5 & $\begin{array}{l}\text { Belum ada kebijakan untuk meningkatkan jumlah kunjungan WUS } \\
\text { untuk melakukan imunisasi MR }\end{array}$ & 0,1 & 1 & 0,1 \\
\hline & \multicolumn{1}{|c|}{ Jumlah } & & 3,25 \\
\hline
\end{tabular}

Berdasarkan analisis dengan menggunakan matriks USG dengan membuat rangking dan total nilai tertinggi, maka faktor yang menjadi prioritas adalah belum ada upaya promotif untuk meningkatkan pengetahuan WUS tentang imunisasi MR di Puksesmas Kecamatan Pasar Minggu. Setelah peneliti mendapatkan faktor utama yang menyebabkan tidak optimalnya imunisasi MR pada WUS, maka tahap selanjutnya adalah membuat analisis Strenght Weaknes Opportunity Threat (SWOT), analisis SWOT dilakukan dengan identifikasi 2 cara yakni identifikasi faktor internal/ IFE (Internal Factor Evaluation) dengan menggunakan matrix untuk menyimpulkan dan mengevaluasi kekuatan dan kelemahan, analisis faktor eksternal/EFE (External Factor Evaluation) dengan menggunakan matrix untuk menyimpulkan dan mengevaluasi peluang dan ancaman. Berikut adalah table IFE dan EFE : 


\begin{tabular}{|c|c|c|c|c|}
\hline \multicolumn{5}{|c|}{ Tabel 3. Matrix Eksternal Faktor Evaluation (EFE) } \\
\hline No. & Kritikal Faktor & Bobot & Rating & Score \\
\hline \multicolumn{5}{|c|}{ Opportunity (Peluang) } \\
\hline 1 & $\begin{array}{l}\text { Pelaksanaan Imunisasi MR didukung oleh Permenkes RI No. } 42 \\
\text { tahun } 2017\end{array}$ & 0,5 & 4 & 2,0 \\
\hline 2 & $\begin{array}{l}\text { Terdapat anggaran dana dalam upaya peningkatan cakupan } \\
\text { imunisasi MR (anak) }\end{array}$ & 0,1 & 3 & 0,3 \\
\hline 3 & Perkembangan ilmu pengetahuan dan teknologi & 0,3 & 4 & 1,2 \\
\hline 4 & Adanya perhatian masyarakat terhadap kesehatan ibu hamil & 0,3 & 4 & 1,2 \\
\hline 5 & Adanya perhatian masyarakat terhadap program imunisasi MR & 0,2 & 3 & 0,6 \\
\hline \multicolumn{4}{|c|}{ Jumlah } & 5,3 \\
\hline & Threats (Ancaman) & & & \\
\hline 1 & $\begin{array}{l}\text { Perbedaan tarif imunisasi MR di masing-masing fasilitas } \\
\text { kesehatan cenderung membuat WUS tidak langsung bersedia } \\
\text { diberikan imunisasi MR }\end{array}$ & 0,4 & 3 & 1,2 \\
\hline 2 & $\begin{array}{l}\text { Adanya kecenderungan deficit anggaran pada program Jaminan } \\
\text { Kesehatan Nasional cenderung membuat Kemenkes RI berupaya } \\
\text { meminimalisir anggaran pelaksanaan upaya pencegahan kejadian } \\
\text { sakit yang bukan prioritas }\end{array}$ & 0,5 & 4 & 2,0 \\
\hline & Jumlah & & & 3,2 \\
\hline
\end{tabular}

Hasil penjumlahan skor bobot dari masing-masing faktor internal dan eksternal adalah sebagai berikut :

$\begin{array}{lll}\text { 1. } & \text { Kekuatan } & : 4,0 \\ \text { 2. Kelemahan } & : 3,25 \\ \text { 3. } & \text { Peluang } & : 5,3 \\ \text { 4. Ancaman } & : 3,2\end{array}$

Berdasarkan peta kekuatan organisasi SWOT dapat disimpulkan bahwa Kebijakan untuk meningkatkan pengetahuan WUS tentang imunisasi MR pada Kebijakan program Imunisasi MR untuk WUS di Wilayah Puskesmas Kecamatan Pasar Minggu berada pada situasi yang sangat menguntungkan, dimana Puskesmas Kecamatan Pasar Minggu memiliki peluang dan kekuatan sehingga dapat memanfaatkan peluang yang ada. Strategi yang diterapkan dalam kondisi ini adalah mengambil peluang untuk meningkatkan minat WUS dalam melakukan imunisasi MR. Masalah utama yang menyebabkan belum optimalnya pelaksanaan imunisasi MR pada WUS di Wilayah Puskesmas Kecamatan Pasar Minggu adalah belum adanya kebijakan untuk meningkatkan pengetahuan WUS dalam melakukan imunisasi MR. Untuk mengatasi masalah tersebut maka dapat dirumuskan beberapa alternative rekomendasi kebijakan guna mengotimalkan pelaksanaan imunisasi MR pada WUS. Adapun beberapa alternative rekomendasi kebijakan operasional tersebut berdasarkan SWOT dan USG Matriks adalah 4 Alternatif Kebijakan Operasional yaitu ; Usulan Penyusunan Standar Operasinal Prosedur Upaya Promotif Kesehatan tentang Imunisasi MR untuk WUS, Usulan Peningkatan Koordinasi antar Tenaga Kesehatan Dalam Promosi Imunisasi MR untuk WUS, Usulan Penyusunan Anggaran Operasional Promosi Imunisasi MR untuk WUS, dan Usulan Menggali Kejadian CRS pada Anak dan Penyakit Campak Rubella pada WUS melalui Kuisioner KPLDH.

Selanjutnya dilakukan identifikasi pemilihan alternatif kebijakan dengan analisis Quantitative Strategies Planning Matrix (QSPM). Hasilnya rekomendasi alternatif kebijakan operasional berdasarkan identifikasi masalah adalah diusulkan beberapa alternatif rekomendasi kebijakan dengan urutan yaitu ; usulan penyusunan standar operasional prosedur upaya promotif kesehatan, usulan peningkatan koordinasi antar tenaga kesehatan dalam promosi kesehatan, usulan penyusunan anggaran operasional promosi kesehatan, dan usulan menggali data kejadian CRS pada anak dan penyakit campak rubella pada WUS melalui kuisioner KPLDH. 
Tabel 4. Analisa Alternatif Kebijakan dengan Metode QSPM

\begin{tabular}{|l|l|c|c|c|c|c|}
\hline No. & \multicolumn{1}{|c|}{ Komponen Dasar } & Bobot & \multicolumn{2}{|c|}{ Strategi } & Jumlah & Peringkat \\
\cline { 4 - 5 } & & & $\begin{array}{c}\text { Atractive } \\
\text { Score }\end{array}$ & $\begin{array}{c}\text { Total } \\
\text { Atractive } \\
\text { Score }\end{array}$ & & \\
\hline 1 & $\begin{array}{l}\text { Melakukan promotif kesehatan tentang } \\
\text { imunisasi MR untuk WUS dengan } \\
\text { berkoordinasi dengan unit lain }\end{array}$ & 0,4 & 3 & 1,2 & 1,6 & 2 \\
\hline 2 & $\begin{array}{l}\text { Menyusun standar operasional prosedur } \\
\text { penyuluhan kesehatan tentang imunisasi } \\
\text { MR untuk WUS }\end{array}$ & 0,4 & 4 & 0,8 & 2,4 & 1 \\
\hline 3 & $\begin{array}{l}\text { Mendata penderita CRS maupun riwayat } \\
\text { campak dan rubella pada WUS melalui } \\
\text { kuisioner KPLDH }\end{array}$ & 0,1 & 1 & 0,1 & 0,2 & 4 \\
\hline 4 & $\begin{array}{l}\text { Mengajukan anggaran promosi kesehatan } \\
\text { tentang imunisasi MR untuk WUS }\end{array}$ & 0,1 & 2 & 0,4 & 0,5 & 3 \\
\hline
\end{tabular}

Berdasarkan hal tersebut maka rekomendasi alternatif kebijakan terpilih adalah penyusunan Standar Operasional Prosedur Upaya Promotif Kesehatan tentang Imunisasi Campak dan Rubela untuk Wanita Usia Subur. Standar Operasional Prosedur (SOP) yang telah disusun kemudian diajukan kepada Kepala Puskesmas dan Tim Imunisasi MR di Puskesmas Kecamatan Pasar Minggu. Hasilnya rekomendasi yang diajukan telah diterima sebagai rekomedasi usulan kebijakan dengan Nomor Dokumen Rek.01/SOP/II/2018 sebanyak 4 halaman yang berisi penjelasan isi standar operasional prosedur, anggaran dana yang diperlukan, serta diagram alur cara pelaksaanan SOP. SOP yang diajukan belum memiliki nomor Surat Keputusan dikarenakan perlu dilakukan uji coba dan evaluasi dalam 3 bulan untuk bisa menjadi Surat Keputusan, dan uji coba akan dilaksanakan mulai bulan Mei 2018 hingga bulan Juli 2018.

Gambaran singkat isi Standar Operasional Prosedur Promotif Kesehatan tentang Imunisasi Campak dan Rubela untuk WUS antara lain berisi tentang : pengertian yakni kegiatan penyuluhan tentang imunisasi campak dan rubella untuk wanita usia subur yang ditampilkan di dalam gedung Puskesmas. Tujuan dari SOP ini adalah tercapainya perubahan pengetahuan, sikap dan tindakan positif dari individu atau masyarakat dalam menaggapi tentang Imunisasi Campak dan Rubella untuk Wanita Usia Subur.
Manfaat SOP ini adalah meningkatnya pengetahuan dan perubahan sikap positif dari WUS dan Masyarakat tentang imunisasi Campak dan Rubella. Sasaran dari kebijakan ini adalah Wanita Usia Subur yang berusia $20-45$ tahun terutama calon pengantin wanita dan calon ibu hamil. Target capaian SOP ini adalah adanya peningkatan kunjungan wanita usia subur untuk medapatkan imunisasi campak dan rubela menjadi minimal 50 kunjungan dalam waktu 3 bulan setelah dilakukan penyuluhan rutin. Pelaksanaan penyuluhan ini rencananya akan dilaksanakan setiap hari Rabu di ruang tunggu obat oleh Tim Imunisasi MR mulai pukul 10.00 WIB. Pelaksana dalam kegiatan penyuluhan ini adalah Tim Imunisasi MR yang terdiri dari Ketua Pelaksana dan Anggota yang bertugas dalam Penanggung Jawab Kegiatan yang bertanggung jawab terhadap pelaksanaan kegiatan di Puskesmas Kecamatan Pasar Minggu, dan Koordinator Lapangan bertugas sebagai humas dengan total jumlah anggota 3 orang. Karakteristik vaksin yang digunakan antara lain vaksin berisi 1000CCID50 virus campak dan 1000CCID virus rubell, vaksin disimpan dalam suhu 2 $-8{ }^{\circ} \mathrm{C}$ tahan 24 bulan, dan vaksin yang telah dilarutkan maksminal digunakan dalam waktu 6 jam jika tidak habis harus dibuang. Cara pemberian vaksin diberikan dalam dosis pemberian $0,5 \mathrm{ml}$, Injeksi diberikan secara subkutan pada lengan atas, setelah diberikan imunisas wajib melakukan penundaan kehamlan minimal 28 hari, dan imunisasi maksimal diberikan 2 kali seumur hidup dengan jarak pemberian 24 - 30 hari. 
Kontra indikasi dari pemberian imunsasi campak dan rubella ini antara lain individu yang sedang dalam terapi kortikosteroid, imunosupresan dan radioterapi, wanita hamil, leukemia, anemia berat dan kelainan darah lainnya, kelainan fungsi ginjal berat, decompensatio cordis, setelah pemberian gamma globulin atau transfusi darah, dan riwayat alergi terhadap komponen vaksin (neomicyn). Pemberian vaksin ditunda apabila ditemukan kondisi ibu deman, batuk, pilek, dan diare.

Dalam melakukan promosi kesehatan hal-hal yang diperlukan antara lain persiapan alat yakni buku tulis untuk notulensi dan absensi, bulpen, komputer dan LCD jika menggunakan power point atau lembar balik, serta leaflet. Persiapan yang diperlukan dalam kegiatan promotif kesehatan ini yakni persiapkan waktu dan tempat dengan bekerja sama dengan unit terkait, persiapan alat, absensi kehadiran peserta, dan pembagian leaflet.

Pelaksanaan kegiatan ini dilakukan dalam beberapa sesi yakni dimulai dengan memberikan salam dan memperkenalkan diri, pemberian materi Pemberian materi penyuluhan, dengan bahasa yang sederhana, suara jelas dan irama tidak membosankan serta selingi dengan humor, uat peserta tertarik untuk berpartipisapasi dan aktif bertanya, jawab pertanyaan dengan jujur dan meyakinkan, berikan kesimpulan, tutup penyuluhan dengan senyum dan ucapkan terima kasih, berikan salam, catat pertanyaan responden beserta jawaban yang diberikan serta kendala dalam penyuluhan, simpan absensi kegiatan dan catatan hasil penyuluhan, serta bereskan kembali alat yang digunakan.

Standar Operasional Prosedur yang telah disusun kemudian diajukan kepada Tim Imunisasi MR dan Kepala Puskesmas Kecamatan Pasar Minggu dengan hasil tanggapan usulan alternatif kebijakan diterima dengan alasan utama bahwa sosialisasi yang dilaksanakan di dalam gedung tidak membutuhkan anggaran biaya yang besar dan dapat menggunakan biaya dari anggaran operasional umum Puskesmas, serta dapat dilaksanakan dengan segera dikarenakan sudah ada Tim Imunisasi MR yang telah memiliki pengalaman dalam pemberian imunisasi MR. Kemudian dalam pelaksanannya, kegiatan adalah kegiatan penyuluhan tentang Imunisasi Campak dan Rubella untuk Wanita Usia Subur yang ditampilkan di dalam gedung Puskesmas.

Kegiatan uji coba usulan rekomendasi penelitian ini rencananya akan dilaksanakan oleh Tim Imunisasai Campak Rubela mulai bulan Mei 2018 sampai dengan Juli dengan target pencapaian adalah peningkatan kunjungan Wanita Usia Subur untuk medapatkan Imunisasi Campak dan Rubela menjadi minimal 50 kunjungan dalam waktu 3 bulan setelah dilakukan penyuluhan rutin. Kemudian hasil kegiatan akan dievaluasi dan diperbaiki sebelum dijadikan Surat Keputusan untuk menjadi standard operasional prosedur yang resmi di Puskesmas Kecamatan Pasar Minggu.

\section{Kesimpulan}

Hasil identifikasi masalah di lokasi penelitian kebijakan imunisasi MR untuk WUS ini adalah belum adanya upaya promotif tentang imunisasi MR untuk WUS, belum ada koordinasi dalam upaya memperkenalkan imunisasi MR antar ruangan di tempat penelitian meliputi ruang poli kebidanan, ruang bersalin dan ruang nifas, dan belum ada anggaran dalam upaya promotif imunisasi MR, serta belum adanya data jumlah penderita campak dan rubella pada ibu hamil atau WUS. Berdasarkan analisis dengan metode USG diperoleh prioritas masalah terpilih adalah belum adanya upaya promotif dalam imunisasi MR untuk WUS.

Rumusan alternatif kebijakan operasional dipilih berdasarkan analisa kebijakan dengan metode SWOT dan QSPM, hasilnya rekomendasi kebijakan terpilih adalah menyusun standar operasional prosedur penyuluhan kesehatan tentang imunisasi MR untuk WUS, yang kemudian disusun dalam bentuk Standar Operasional Prosedur Upaya Promotif Imunisasi Campak dan Rubela pada Wanita Usia Subur, yang berisi acuan kegiatan, diagram alur dan anggaran biaya yang diperlukan dalam setiap kegiatan penyuluhan kesehatan. 
Saran yang diberikan untuk lahan penelitian adalah diharapkan dapat segera disusun kebijakan tentang upaya promotif pemberian imunisasi Campak dan Rubela dengan prioritas sasaran adalah WUS untuk mencegah kejadian Campak dan Rubela pada ibu hamil dan kejadian CRS pada bayi baru lahir.

\section{Daftar Pustaka}

1. Kementerian Kesehatan RI. "Profil Kesehatan Indonesia," Profil Kesehatan Indonesia, hal. 100. Tersedia pada: http://www.depkes.go.id/resources/

download/ pusdatin/ lain-lain/ Data dan Informasi Kesehatan Profil Kesehatan Indonesia 2016 - smaller size - web.pdf ; 2017.

2. Kader, Ç. et al. (2016) "Immunity of nursing students to measles, mumps, rubella, and varicella in Yozgat, Turkey," American Journal of Infection Control, 44(1), hal. e5e7. doi: 10.1016/j.ajic.2015.08.021.; 2016.

3. World Health Organization."World Health Statistics - Monitoring Health For The SDGs," World Health Organization, hal. 1.121. doi: 10.1017/ CBO97811074 $15324.004 ; 2016$.

4. Lazar, M. et al. . "Immunolocalization and Distribution of Rubella Antigen in Fatal Congenital Rubella Syndrome," EBioMedicine. Elsevier B.V., 3, hal. 86-92. doi: 10.1016/j.ebiom.2015.11.050.; 2016.

5. Kementerian Kesehatan RI. "Permenkes RI No. 39 tahun 2016 tentang Pedoman umum program Indonesia sehat dengan pendekatan keluarga," Kemenkes RI, hal. 39.; 2016.

6. Cameron, N. A. "When, and how, should we introduce a combination measles-mumpsrubella (MMR) vaccine into the national childhood expanded immunization programme in South Africa?," Vaccine. Elsevier Ltd, 30(SUPPL.3), hal. C58-C60. doi: 10.1016/j.vaccine.2012.02.082; 2012.

7. Kementerian Kesehatan RI. "Peraturan Menteri Kesehatan No.43 Tahun 2016 tentang Standar Pelayanan Minimal Bidang Kesehatan,” 31 Agustus 2016 ; 2016.

8. Creswell, W John. Qualitative Inquiry and Research Design: Choosing Among Five Approaches. Thousand Oaks, California: SAGE Publication ; 2007.

9. Kementerian Kesehatan RI (2014) "Peraturan Menteri Kesehatan Republik Indonesia Nomor 75 Tahun 2014 tentang Pusat Kesehatan Masyarakat,” 2014, hal. 1-
24. doi: 10.1017/CBO9781107415324.004. ; 2014.

10. Imron, Moch. Munif, Amrul; 2010, Metodologi Penelitian Bidang Kesehatan, Jakarta: Sagung Seto ; 2010.

11. Notoatmodjo. Metodologi Penelitian. Jakarta : Rhineka Cipta ; 2010.

12. Riduwan. Belajar Mudah Penelitian. Alfabeta : Bandung ; 2012.

13. Radji, Maksum dan Harmita. Buku Ajar Analisis Hayati. Jakarta : EGC ; 2010.

14. Moloeng, 1.J. Metode Penelitian Kualitatif. Bandung : Rosda Ofsett ; 2010.

15. Adisasmito, Wiku. Buku Ajar Kebijakan Kesehatan. Jakarta : Departeman Administrasi dan Kebijakan Kesehatan, Fakultas Kesehatan Masyarakat Universitas Indonesia ; 2007.

16. Burhan. Metodologi Penelitian Sosial, Format-Format Kuantitif dan Kualitatif. Surabaya: Airlangga University Press ; 2007.

17. Raco.J.R. Metode Penelitian Kualitatif. Penerbit PT Grasindo : Jakarta ; 2010.

18. Radji, Maksum dan Harmita. Buku Ajar Analalisis Hayati. Jakarta : EGC ; 2010.

19. Imron, Moch. \& Munif, Amrul. Metodologi Penelitian Bidang Kesehatan, Jakarta: Sagung Seto ; 2010.

20. Miles, M.B. \& Huberman, A.M. Qualitative data analysis: An expanded sourcebook. New York : SAGE Publication ; 2008. 